\title{
HUBUNGAN PENGETAHUAN DAN PERAN PETUGAS KESEHATAN DENGAN PERAWATAN TALI PUSAT DI PUSKESMAS SUGIH WARAS
}

\author{
Rohmaniyah ', Minarti ${ }^{2}$ \\ Program Studi DIV Kebidanan Falkultas Kebidanan Dan Keperawatan Universitas Kader Bangsa Palembang \\ Jalan H.M. Ryacudu No. 887 Ulu Palembang \\ Email : rohmaniyah1110@gmail.com
}

\begin{abstract}
Abstrak
World Health Organization (WHO) menyebutkan, pusat penyebab utama kematian bayi adalah tetanus dan penyakit infeksi Tujuan dalam penelitian ini adalah Diketahui hubungan pengetahuan dan peran petugas kesehatan secara simultan dengan perawatan tali pusat di Wilayah Kerja Puskesmas Sugih Waras Kecamatan Rambang Kabupaten Muara Enim Tahun 2019. Penelitian ini bersifat kualiitatif menggunakan metode survey analitik yaitu survey atau penelitian yang mencoba menggali bagaimana dan mengapa fenomena kesehatan itu terjadi (Notoatmodjo, 2012). Dengan pendekatan cross sectional. Sampel yang diteliti dalam penelitian ini adalah semua ibu nifas yang mempunyai bayi yang berumur 0 28 hari di Wilayah Kerja Puskesmas Sugi Waras yang berjumlah 30 responden. Hasil analisa univariat menjukan bahwa dari 30 responden yang diteliti, ada 21 responden (70,0\%) yang melakukan perawatan tali pusat dengan menggunakan kassa steril dan mencuci tali pusat dengan air bersih, lebih besar dibandingkan responden yang tidak melakukan perawatan melakukan perawatan tali pusat dengan menggunakan kassa steril dan mencuci tali pusat dengan air bersih sebanyak 9 responden (30,0\%). Hasil uji Chi-Square didapat nilai p.value pengetahuan 0,002, Sikap 0,013 dan Peran Petugas Kesehatan $0,003<\alpha=0,05$. Saran kepada pimpinan puskesmas diharapkan agar penelitian ini dapat dijadikan bahan pertimbangan dalam pengambilan keputusan, dapat meningkatkan mutu pelayanan dan penyuluhan khususnya tentang perawatan tali pusat.
\end{abstract}

Kata kunci : Perawatan Tali Pusat, Pengetahuan, Dan Peran Petugas Kesehatan

\begin{abstract}
The World Health Organization (WHO) states that the main causes of infant mortality are tetanus and infectious diseases. This study aimed to fine out the relationship among mothers' knowledge, mothers' attitude, and the role of health workers Disrtict of Rambang, Disrtict of Muara Enim in 2019. This study was qualitative using analytical survay method, survay or research that tries to explore how and why health phenomena accur ( notoatmojo, 2012. With cross sectional approach. The population in this study was all postpartum mothers who had babies aged 0-28 days with the total samples of 30 respondents. The results of the univariate analysis showed that 21 respondents (70\%) took care of the umbilical cord by using sterile gauze and wash it with clean water greater than those who did not do it, 9 respondents (30\%). Chi-square statistical test results showed that $p$ value obtained for knowledge was 0,002 , attitude 0,013, and role of health workers $0,003<\alpha 0,05$ meaning that there was a relationship among mothers' knowledge, mothers' attitude, and the role of health workers simultaneously and umbilical cord care in the Puskesmas in 2019. This study results are expected to be learning material for midwives in giving service mainly for umbilical core care to prevent in newborns.
\end{abstract}

\section{Keywords : Umbilical Core Care, Knowledge, and Role of Health Workers}




\section{PENDAHULUAN}

Perawatan tali pusat merupakan tindakan keperawatan yang bertujuan merawat tali pusat pada bayi baru lahir agar tetap kering dan mencegah terjadinya infeksi pada tali pusat bayi, alat dan bahan yang digunakan hanya kassa steril, air dan sabun (Hidayat, 2009).

World Health Organization (WHO) menyebutkan, pusat penyebab utama kematian bayi adalah tetanus dan penyakit infeksi. Tetanus neonatorum dan infeksi tali pusat menjadi penyebab kesakitan dan kematian secara terus menerus diberbagai Negara. Setiap tahunnya 500.000 bayi meninggal karena tetanus neonatorum dan 460.000 meninggal akibat infeksi bakteri. Infeksi ini dapat terjadi akibat perawatan atau tindakan yang tidak memenuhi syarat kebersihan misalnya pemotongan tali pusat dengan menggunakan bambu atau gunting yang tidak steril, atau setelah tali pusat dipotong dibubuhi abu, tanah, minyak, daun-daunan dan sebagainya. Tali pusat mempunyai resiko besar untuk terkontaminasi oleh clostridium tetani pada 3 hari pertama kehidupan (Sodikin, 2015).

Dalam 5 tahun terakhir (2010-2015), Angka Kematian Neonatal (AKN) tetap sama yakni 19/1000 kelahiran, sementara untuk Angka Kematian Pasca Neonatal (AKPN) terjadi penurunan dari 15/1000 menjadi 13/1000 kelahiran hidup, angka kematian anak balita juga turun dari 44/1000 menjadi 40/1000 kelahiran hidup. Menurut data Departemen Kesehatan, 75\% kematian bayi terjadi pada masa perinatal. Kematian neonatal kelompok umur 8-28 hari tertinggi adalah infeksi sebesar $57,1 \%$ (termasuk tetanus, sepsis, pneumonia, diare), proporsi kematian karena Tetanus Neonatorum yaitu 9,5\% akibat dari infeksi perawatan tali pusat (Kementerian Kesehatan Republik Indonesia, 2015).

Angka Kematian Bayi terdapat 53 per 100 kelahiran, atau turun $25 \%$ selama 10 tahun atau rata-rata turun $2,5 \%$ pertahun. Angka Kematian BayiSumatera Selatan lebih tinggi dibandingkan angka nasional yaitu 42 per 1000 kelahiran hidup. Penyebab bayi disebabakan karena Bayi Berat Lahir Rendah, Tetanus Neonatorum dan perinatal, Menurut target MDGs, AKB diharapkan turun menjadi 23 per 1000 kelahiran hidup. Kematian bayi di Sumatera Selatan tahun 2011 adalah 4,3\%, pada tahun 2012 sebesar 3,3\% dan pada tahun 2014 sebesar 2,8\% (Profil Dinas Kesehatan Provinsi Sumatera Selatan, 2015).

Faktor-faktor yang mempengaruhi perawatan tali pusat adalah cara perawatan tali pusat, kelembaban tali pusat, adanya kondisi sanitasi lingkungan yaitu virus spora clostridium yang tidak memenuhi syarat kebersihan, sikap ibu dalam merawat tali pusat bayinya serta peran petugas kesehatan (Saleha, 2013).

Sikap merupakan reaksi atau respon seseorang yang masih tertutup terhadap stimulasi atau objek. Salah seorang ahli psikologis sosial, menyatakan bahwa sikap merupakan kesiapan atau kesediaan untuk bertidak dan bukan merupakan pelaksanaan motif tertetu. Sikap merupakan kesiapan untuk bereaksi terhadap objek di lingkungan tertentu sebagai suatu penghayatan terhadap objek (Notoatmodjo,2012).

Peran merupakan suatu kegiatan yang bermanfaat untuk mempelajari interaksi antara individu sebagai pelaku (actors) yang menjalankan berbagai macam peranan di dalam hidupnya, seperti dokter, perawat, bidan atau petugas kesehatan lain yang mempunyai kewajiban untuk menjalankan tugas atau kegiatan yang sesuai dengan peranannya masing-masing (Muzaham, 2015).

\section{METODE PENELITIAN}

\section{Jenis Penelitian}

Penelitian ini bersifat kualiitatif menggunakan metode survey analitik yaitu survey atau penelitian yang mencoba menggali bagaimana dan mengapa 
fenomena kesehatan itu terjadi (Notoatmodjo, 2012). Dengan pendekatan cross sectional yaitu suatu penelitian untuk mempelajari dinamika korelasi anatra faktor-faktor risiko dengan efek, dengan cara pendekatan, observasi atau pengumpulan data sekaligus pada suatu saat (point time approach) (Notoatmodjo, 2012), dimana penelitian dilakukan dengan mengukur variabel independen (pengetahuan, sikap ibu dan peran petugas kesehatan) dan variabel dependen (perawatan tali pusat) dalam waktu bersamaan (Notoadmodjo, 2012).

\section{Waktu dan Tempat Penelitian}

Penelitian ini sudah dilaksanakan pada bulan April-Mei tahun 2019. Dan Penelitian ini sudah dilaksanakan di Wilayah Kerja Puskesmas Sugih Waras Kecamatan Rambang Kabupaten Muara Enim.

\section{Populasi dan Sampel}

Populasi adalah keseluruhan objek penelitian atau objek yang diteliti (Notoatmodjo, 2014). Populasi dalam penelitian ini adalah semua ibu nifas yang mempunyai bayi usia 0-28 hari di Wilayah Kerja Puskesmas Sugih Waras Kecamatan Rambang Kabupaten Muara Enim. Yang berjumlah 30 responden.

Sampel adalah objek yang diteliti dan dianggap mewakili seluruh populasi. Sampel yang diteliti dalam penelitian ini adalah semua ibu nifas yang mempunyai bayi yang berumur 0-28 hari di Wilayah Kerja Puskesmas Sugi Waras. Pengambilan sampel dilakukan dengan cara non-random sampling dengan teknik Accidental sampling, dimana pengambilan sampel secara aksidental (Accidental) ini dilakukan dengan mengambil kasus responden yang kebetulan ada atau tersedia yaitu mengambil sampel sesuai dengan jumlah sampel yang ada pada penelitian dengan menggunakan 30 responden (Notoadmodjo, 2012).

\section{Teknik Pengumpulan Data}

Data yang dikumpulkan dalam penelitian ini berupa data primer. Data primer adalah data yang diperoleh dari wawancara langsung kepada responden dengan menggunakan kuesioner.

\section{Teknik Analisis Data}

\section{Analisis Univariat}

Analisis ini bertujuan untuk mengetahui distribusi frekuensi dan presentase dari tiap variabel yaitu variabel independen (pengetahuan, sikap ibu dan peran petugas kesehatan) dan variabel dependen (perawatan tali pusat).

\section{Analisis Bivariat}

Analisis bivariat bertujuan untuk melihat hubungan antara variabel independen (pengetahuan, sikap ibu dan peran petugas kesehatan) dengan variabel dependen (perawatantali pusat) dengan menggunakan uji statistik Chi Square. Dengan tingkat kemaknaan $\alpha=0,05$ dan tingkat kepercayaan $95 \%$.

Dengan keputusan statistik :

1. Jika pvalue $\leq \alpha(0,05)$, maka $\mathrm{H}_{0}$ ditolak artinya ada hubungan bermakna antara variabel yang diuji.

2. Jika $\mathrm{p}$ value $>\alpha(0,05)$, maka $\mathrm{H}_{0}$ diterima artinya tidak ada hubungan bermakna antara variabel yang diuji. 


\section{HASIL PENELITIAN DAN PEMBAHASAN}

Analisis Univariat

Tabel 1. Distribusi Frekuensi dan Persentase Responden Berdasarkan Perawatan Tali Pusatdi Puskesmas Sugih Waras Kecamatan Rambang Kabupaten Muara Enim tahun 2019

\begin{tabular}{llcc}
\hline No & $\begin{array}{l}\text { Perawatan } \\
\text { Tali Pusat }\end{array}$ & $\begin{array}{c}\text { Frekuensi } \\
(\mathbf{N})\end{array}$ & $\begin{array}{c}\text { Persen } \\
\text { tase }(\boldsymbol{\%})\end{array}$ \\
\hline 1 & Ya & 21 & 70,0 \\
\hline 2 & Tidak & 9 & 30,0 \\
\hline & Jumlah & $\mathbf{3 0}$ & $\mathbf{1 0 0}$ \\
\hline
\end{tabular}

(Sumber : Output SPSS, 2019)

Berdasarkan tabel diatas dapat dilihat bahwa dari 30 responden yang diteliti, ada 21 responden $(70,0 \%)$ yang melakukan perawatan tali pusat dengan menggunakan kassa steril dan mencuci tali pusat dengan air bersih, lebih besar dibandingkan responden yang tidak melakukan perawatan melakukan perawatan tali pusat dengan menggunakan kassa steril dan mencuci tali pusat dengan air bersih sebanyak 9 responden $(30,0 \%)$.

Tabel 2. Distribusi Frekuensi dan Persentase Responden Berdasarkan Pengetahuan Ibu di Puskesmas Sugih Waras Kecamatan Rambang Kabupaten Muara Enim tahun 2019

\begin{tabular}{cccc}
\hline No & $\begin{array}{c}\text { Pengetahu } \\
\text { an Ibu }\end{array}$ & $\begin{array}{c}\text { Frekuensi } \\
(\mathbf{N})\end{array}$ & $\begin{array}{c}\text { Persenta } \\
\text { se }(\%)\end{array}$ \\
\hline 1 & Baik & 17 & 56,7 \\
\hline 2 & Kurang Baik & 13 & 43,3 \\
\hline & Jumlah & $\mathbf{3 0}$ & $\mathbf{1 0 0}$
\end{tabular}

(Sumber : Output SPSS, 2018)

Berdasarkan tabel diatas dapat dilihat bahwa dari 30 responden yang diteliti, yang berpengetahuan baiks ebanyak 17 responden $(56,7 \%)$ lebih besar dibandingkan dengan ibu nifas yang berpengetahuan kurang baiksebanyak 13 responden $(43,3 \%)$.
Tabel 3. Distribusi Frekuensi dan Persentase Responden Berdasarkan Peran Petugas Kesehatan di Puskesmas Sugih Waras Kecamatan Rambang Kabupaten Muara Enim tahun 2019

\begin{tabular}{clcc}
\hline No & $\begin{array}{l}\text { Peran } \\
\text { Petugas } \\
\text { Kesehatan }\end{array}$ & $\begin{array}{c}\text { Frekuensi } \\
(\mathbf{N})\end{array}$ & $\begin{array}{c}\text { Persen } \\
\text { tase } \\
(\mathbf{\%})\end{array}$ \\
\hline 1 & Baik & 22 & 73,3 \\
\hline 2 & Kurang Baik & 8 & 26,7 \\
\hline & Jumlah & $\mathbf{3 0}$ & $\mathbf{1 0 0}$ \\
\hline (Sumber : Output SPSS, 2019) & \\
& &
\end{tabular}

Berdasarkan tabel diatas dapat dilihat bahwa dari 30 responden yang diteliti, petugas kesehatan yang memberikan perannya dengan baik sebanyak 22 responden (73,3\%) lebih besar dibandingkan petugas kesehatan yang memberikan perannya degan kurang baik sebanyak 8 responden $(26,7 \%)$.

\section{Analisis Bivariat}

Tabel 4. Persentase Hubungan Pengetahuan Ibu dengan Perawatan Tali Pusat di Puskesmas Sugih Waras Kecamatan Rambang Kabupaten Muara Enim Tahun 2019

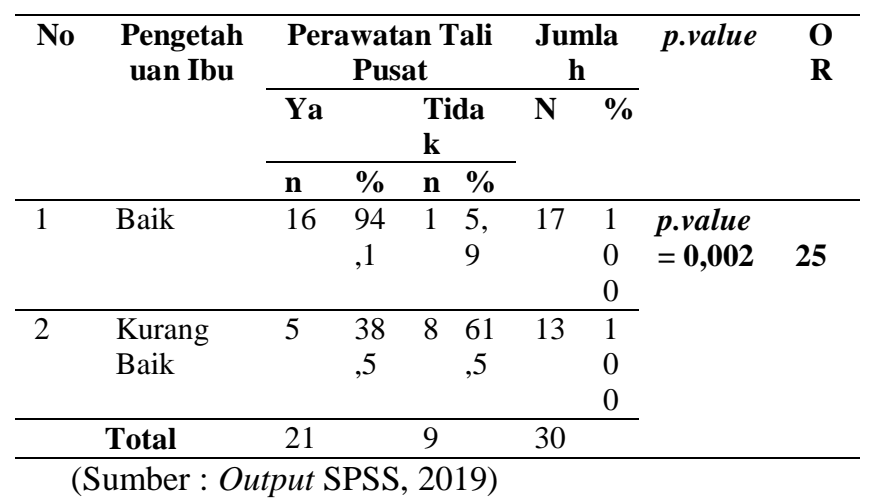

Berdasarkan tabel 5.5 diatas, dapat dilihat bahwa dari 17 responden yang berpengetahuan baik dan melakukan perawatan tali pusat sebanyak 16 responden $(94,1 \%)$ dan yang tidak berjumlah 1 responden $(5,9 \%)$. Sedangkan dari 13 responden yang berpengetahuan kurang baik dan melakukan perawatan tali pusat sebanyak 5 responden $(38,5 \%)$ lebih 
kecil dibandingkan dengan yang tidak melakukan perawatan tali pusat yaitu sebanyak 8 responden $(61,5 \%)$.

Hasil uji Chi-Square didapat nilai p.value $0,002<\alpha=0,05$. Hal ini berarti ada hubungan yang bermakna antara pengetahuan ibu dengan perawatan tali pusat. Hipotesis yang menyatakan ada hubungan yang bermakna antara pengetahuan ibu dengan perawatan tali pusat terbukti secara statistik.

Nilai odds ratio didapat 25 artinya yang pengetahuan ibu baik memiliki peluang 25 kali lebih besar melakukan perawatan tali pusat dibandingkan dengan yang cara perawatan tali pusat dengan kurang baik.

Tabel 5. Persentase Hubungan Peran Petugas Kesehatan dengan Perawatan Tali Pusat di Puskesmas Sugih Waras Kecamatan Rambang Kabupaten Muara Enim Tahun 2019

\begin{tabular}{|c|c|c|c|c|c|c|c|c|c|}
\hline \multirow[t]{3}{*}{$\begin{array}{l}\mathbf{N} \\
\mathbf{0}\end{array}$} & \multirow{3}{*}{$\begin{array}{l}\text { Peran } \\
\text { Petuga } \\
\text { s } \\
\text { Keseh } \\
\text { atan }\end{array}$} & \multicolumn{3}{|c|}{$\begin{array}{l}\text { Perawatan } \\
\text { Pusat }\end{array}$} & Tali & \multicolumn{2}{|c|}{ Jumlah } & \multirow[t]{3}{*}{$\begin{array}{l}\text { p.val } \\
\text { ue }\end{array}$} & \multirow[t]{3}{*}{$\begin{array}{l}\mathbf{O} \\
\mathbf{R}\end{array}$} \\
\hline & & \multicolumn{2}{|c|}{$\mathbf{Y a}$} & \multicolumn{2}{|c|}{ Tidak } & \multirow[t]{2}{*}{$\mathbf{N}$} & \multirow[t]{2}{*}{$\%$} & & \\
\hline & & $\mathbf{n}$ & $\%$ & $\mathbf{n}$ & $\%$ & & & & \\
\hline 1 & Baik & $\begin{array}{l}1 \\
9\end{array}$ & $\begin{array}{l}86, \\
4\end{array}$ & 3 & $\begin{array}{l}13, \\
6\end{array}$ & $\begin{array}{l}2 \\
2\end{array}$ & $\begin{array}{l}10 \\
0\end{array}$ & $\mathbf{0 , 0 0 3}$ & 19 \\
\hline 2 & $\begin{array}{l}\text { Kuran } \\
\text { g Baik }\end{array}$ & 2 & $\begin{array}{l}25, \\
0\end{array}$ & 6 & $\begin{array}{l}75, \\
0\end{array}$ & 8 & $\begin{array}{l}10 \\
0\end{array}$ & & \\
\hline & tal & $\begin{array}{l}2 \\
1\end{array}$ & & 9 & & $\begin{array}{l}3 \\
0\end{array}$ & & & \\
\hline
\end{tabular}

Berdasarkan tabel 5.7 diatas, dapat dilihat bahwa dari 22 responden yang peran petugas kesehatannya baikdan melakukan perawatan tali pusat sebanyak 19 responden $(86,4 \%)$ lebih banyak dibandingkan dengan responden yang peran petugas kesehatannya kurang baik dan tidak melakukan perawatan tali pusat sebanyak 3 responden (13,6\%). Sedangkan dari 8 responden yang peran petugas kesehatannya kurang baik melakukan perawatan tali pusat sebanyak 2 responden $(25,0 \%)$, lebih kecil dibandingkan dengan yang tidak melakukan perawatan tali pusat yaitu sebanyak 6 responden $(61,5 \%)$.
Hasil uji Chi-Square didapat nilai p.value $0,003<\alpha=0,05$. Hal ini berarti ada hubungan yang bermakna antara peran petugas kesehatan dengan perawatan tali pusat. Hipotesis yang menyatakan ada hubungan antara peran petugas kesehatan dengan perawatan tali pusat terbukti secara statistik.

Nilai odds ratio didapat 19 artinya yang peran petugas kesehatannya baik memiliki peluang 19 kali lebih besar menyebabkan ibu nifas untuk melakukan perawatan tali pusat dibandingkan dengan yang peran petugas kesehatannya kurang baik.

\section{KESIMPULAN}

Berdasarkan uraian dan pembahasan hasil penelitian yang telah dilakukan dapat ditarik kesimpulan sebagai berikut :

a. Ada hubungan penegtahuan dan peran petugas kesehatan secara simultan dengan perawatan tali pusat di Puskesmas Sugih Waras Kecamatan Rambang Kabupaten Muara Enim tahun 2019.

b. Ada hubungan pengetahuan ibu secara parsial dengan perawatan tali pusat di Puskesmas Sugih Waras Kecamatan Rambang Kabupaten Muara Enim tahun 2019.

c. Ada hubungan peran petugas kesehatan secara parsial dengan perawatan tali pusat di Puskesmas Sugih Waras Kecamatan Rambang Kabupaten Muara Enim tahun 2019.

\section{SARAN}

a. Kepada Puskesmas Sugih Waras

Diharapkan hasil penelitian ini menjadi bahan pembelajar untuk bidan dalam memberikan pelayanannya terutama pada perawatan tali pusat bayi untuk mencegah terjadinya infeksi pada bayi baru lahir melalui tali pusat.

\section{b. Kepada Rektor Universitas Kader Bangsa Palembang}


Diharapkan dapat digunakan sebagai referensi dan bahan kepustakaan untuk dapat meningkatkan kualitas pendidikan bagi mahasiswi khususnya Program Studi Diploma IV Kebidanan Klinik Universitas Kader Bangsa dan mahasiswi kesehatan lain pada umumnya.

\section{c. Bagi Peneliti yang akan Datang}

Diharapkan penelitian ini sebagai bahan acuan bagi peneliti yang akan datang yang ingin melakukan penelitian terhadap perawatan tali pusat dengan variabel yang berbeda dan sampel yang lebih banyak lagi sebagai upaya pencegahan terjadinya tetanus neonatorum melalui infkesi tali pusat pada bayi baru lahir.

\section{UCAPAN TERIMA KASIH}

Saya ucapkan terimakasih kepada pimpinan puskesmas Sugih Waras kec. Rambang Kab. Muara Enim, kepada pembimbing saya ibu Eka Afrika SST, M. Kes dan ibu Minarti, SST, M. Kes, dan kepada keluaraga besar saya yang telah memberikan dukungan financial maupun moril, dan sahabat saya Sumartini ( nunik), Tiara Senja atas dukungan nya.

\section{DAFTAR PUSTAKA}

Azwar. 2010. Obstetri Williams Panduan Ringkas. Jakarta : EGC.

Benson. 2013. Buku Saku Obstetri dan Ginekologi. Jakarta. EGC.

Dewi, Vivian Nanny Lia, dan Tri Sunarsih. 2014. Asuhan Neonatus, Bayi, dan Anak Balita. Salemba Medika, Jakarta.

. 2010. Ilmu Kesehatan Anak untuk Pendidikan Kebidanan. Jakarta. Salemba Medika.
Hidayat. 2014. Ilmu Kesehatan Anak untuk Pendidikan Kebidanan. Jakarta. Salemba Medika.

Manuaba, I.B.G. 2014. Ilmu Kebidanan, Penyakit Kandungan dan Keluarga Berencana Untuk Pendidikan Bidan. Jakarta : EGC

Muzaham. 2015. Sosiologi Kesehatan. Jakarta : Universitas Indonesia. . Metodologi Penelitian Kesehatan Edisi Revisi. Jakarta : Rineka Cipta.

Notoatmodjo. 2012. Metodologi Penelitian Kesehatan Edisi Revisi. Jakarta : Rineka Cipta.

Prawirohardjo, Sarwono. 2014. Ilmu Kebidanan. Jakarta. Yayasan Bina Pustaka Sarwono Prawirohardjo.

Saleha, Siti. 2013. Asuhan Kebidanan Pada Masa Nifas. Jakarta : Salemba Medika . 2012. Buku Saku Perawatan Tali

Pusat. Jakarta : EGC.

Sodikin. 2015. Buku Saku Perawatan Tali Pusat. Jakarta : EGC.

Suririnah, 2014. Buku Pintar Mengasuh Batita. Jakarta. Gramedia Pustaka.

Dinas Kesehatan Kota Palembang. 2016. Profil Kesehatan Kota Palembang 2016.

http://dinkes.palembang.go.id/tampu ng/dokumen/dokumen-122-166.pdf, diakses tanggal 19 April 2019.

Kemenkes RI, 2016. Profil Kesehatan Indonesia Tahun 2015. www.depkes.go.id/.../profilkesehatan-indonesia/profilkesehatan-indonesia-2013.pdf, diakses tanggal 19 April 2019. 
Profil Dinas Kesehatan Provinsi Sumatera Selatan. 2016. Profil Kesehatan Provinsi Sumatera Selatan 2015. dinkes.sumselprov.go.id/downlot.p hp?file=PROFILDINASKESEHA TAN2016.pdf, diakses tanggal 19 April 2019

Rahmawati, 2014. Hubungan Antara Karakteristik Ibu, Peran Petugas Kesehatan dan Dukungan Keluarga Dengan Kunjungan Masa Nifas di Wilayah Kerja Puskesmas Bonto Cani Kabupaten Bone. http://ejurnal.poltekkestjk.ac.id/index.php/JKEP/article/vie w/376, diakses tanggal 19 April 2019

Ramadona. 2014. Hubungan Pengetahuan dan Sikap Ibu dengan Perawatan Tali Pusat pada Bayi Usia 0-28 Hari di Kota Padang Panjang tahun 2016. http://lppm.stikesnu.com/wpcontent/uploads/2014/02/8-

Nurhadi.pdf, diakses tanggal 19 April 2019

Sulasikin. 2014. Hubungan Cara Perawatan Tali Pusat dengan Perawatan Tali Pusat pada Bayi Baru Lahir di BPM Mujiasih Pandak Bantul Yogyakarta tahun 2014. http://online-

journal.unja.ac.id/index.php/kedokte ran/article/view/1248, diakses tanggal 19 April 2019

Purnamasari. 2015. Hubungan Dukungan Suami dan Peran Petugas Kesehatan dengan Lama Lepas Tali Pusat di Desa Sukaraja Kecamatan Rajapaloh Kabupaten Tasikmalaya tahun 2015. Jurnal. Program Studi Sekolah Tinggi Ilmu Kesehatan Program Studi Bidan Pendidik Jenjang DIV Sekolah Tinggi Ilmu
Kesehatan 'Aisyiyah Yogyakarta Bidan Pendidik Jenjang DIV

Susanti. 2015. Perawatan Tali Pusat pada Bayi Baru Lahir di Puskesmas Panjatan 1 Kulonprogo tahun 2015. journal.unair.ac.id/downloadfullpapers-pmnj2bf177dc35full.doc, diakses Tanggal 19 April 2019 